\title{
BIOGAS POTENTIAL FROM UNDERWOOD PLANTS
}

\author{
Vilis Dubrovskis, Imants Plume, Dagnis Dubrovskis \\ Latvia University of Life Sciences and Technologies, Latvia \\ vilisd@inbox.lv, imants.plume@1lu.lv, dagnis.dubrovskis@1lu.lv
}

\begin{abstract}
Adherence to the principles of sustainable forest management and increasing economic efficiency is one of the most important tasks of forest management. Therefore, new forest products are being developed in the world and also in Latvia, which are in demand in the market and increase the income of the landowner. In many European countries, in addition to growing valuable timber in stands, attention is being paid to the possibilities of developing the cultivation of ground cover plants and undergrowth biomass by creating cultivated plantations under tree crowns. The forest growing cycle is long, timber production per unit area is cyclical, it repeats every 20 years. Regular production of biomass through the cultivation of undergrowth and ground cover plants can ensure regular production of hitherto little-used biomass, which has an additional economic effect. For example, in fertile growing conditions, clearings and young stands are often overgrown with wild raspberries, which are heavily devoted to harvesting and shading future trees. Biomass from caring for young plants can be used for energy. At the same time, due to the reduction of mandatory procurement, cheaper raw materials are needed to survive in biogas plants. In this study, the biogas production potential from three Latvian underwood plants was tested: ferns (filice), thistles (carduus) and wild raspberries (silva amet) leaves and stalks. These plants were treated in 16 laboratory bioreactors at $38^{\circ} \mathrm{C}$ for 40 days under anaerobic conditions. From ferns $0.274 \mathrm{~L} \cdot \mathrm{g}^{-1} \mathrm{DOM}$ biogas, $0.06 \mathrm{~L} \cdot \mathrm{g}^{-1}$ DOM methane was obtained. $0.703 \mathrm{~L} \cdot \mathrm{g}^{-1}$ DOM biogas $\left(0.256 \mathrm{~L} \cdot \mathrm{g}^{-1}\right.$ DOM methane) was obtained from thistle and $0.511 \mathrm{~L} \cdot \mathrm{g}^{-1}$ DOM biogas $\left(0.191 \mathrm{~L} \cdot \mathrm{g}^{-1}\right.$ DOM methane) from raspberry leaves and stalks. The study shows that thistle and raspberry leaves and stalks are suitable as a raw material for biogas production. Further research is needed to find out why bacteria make poor use of fern biomass.
\end{abstract}

Keywords: anaerobic digestion, biogas, fern, thistle, wild raspberries.

\section{Introduction}

The implementation of the EU Green Deal brings with it new opportunities to scale-up biogas and biomethane in Europe. "At the end of 2019, we have reached a total of 18,943 biogas plants and 725 biomethane plants across Europe. Biogas and biomethane are accessible sources of renewable energy: the sector is ready for expansion and perfectly placed to make a significant and sustainable contribution to the EU Green Deal. A supportive and consistent legislative framework will accelerate ongoing progress and encourage investment, helping sector to reach a minimum of $380 \mathrm{TWh}$ by 2030 , with further growth in the years thereafter" [1].

In Latvia, the state's initial support for biogas production is constantly being reduced. Even previously accepted aid conditions are not taken into account. Restrictions on the use of maize silage as a feedstock in biogas plants and new requirements for the use of larger quantities of manure were developed. Prices for raw material also increased. The financial situation of the producers of biogas has deteriorated and some owners have already ceased operation of biogas plant. Therefore, the use of new, inexpensive raw biomass would be very important for them [2]. Undergrowth biomass could be cheap, as it is not yet fully utilized. Adherence to the principles of sustainable forest management and increasing economic efficiency is one of the most important tasks of forest management. Therefore, new forest products are being developed in the world and also in Latvia, which are in demand in the market in the future and increase the income of the landowner. Much attention is paid to the use of biomass for energy. In many European countries, in addition to growing valuable timber in stands, attention is being paid to the possibilities of developing the cultivation of ground cover plants and undergrowth biomass by creating cultivated plantations under tree crowns. The forest growing cycle is long, timber production per unit area is cyclical, it repeats every 20 years. Regular production of biomass through the cultivation of undergrowth and ground cover plants can ensure regular production of hitherto little-used biomass, which has an additional economic effect. For example, in fertile growing conditions, clearings and young stands are often overgrown with wild raspberries, which are heavily devoted to harvesting and shading future trees. Biomass from caring for young plants can be used for energy.

Information on the use of undergrowth plants used in our study for biogas production could not be found in the literature. We found an article that wetland ferns were good for biogas production. 
"Consequently, the results of our study depicted that this fern, which is known as threat, can be used as an alternative biomass feedstock for efficient power generation and indicates that biogas from Azolla fern biomass had excellent and considerable ability in order to generate power and less NOX emission" [3].

In this study, the biogas production potential from three Latvian underwood plants was tested: fern (filice), thistle (carduus) and wild raspberry (silva amet) leaves and stalks. An extended study is needed to assess the cost-effectiveness, but this is not the aim of this work.

\section{Materials and methods}

The methodologies, similar with German VDI 4630 (VDI 4630, 2006) [4], (Angelidaki et.al. 2009) [5] guideline and the German Methodenhandbuch Energetische Biomassenutzung (Thran, 2010) [6] were used for the present study. An average sample for each group of raw materials was taken and the total dry matter, organic dry matter and content of ashes were measured. The analysis was performed according to standard methods. Each group's raw material was thoroughly weighed carefully. These plants were treated in 16 laboratory bioreactors at $38{ }^{\circ} \mathrm{C}$ for 40 days under anaerobic conditions. All bioreactors (volume of $0.75 \mathrm{~L}$ ) were filled with the same amount $(500.0 \mathrm{~g})$ of inoculums. Inoculums were digestate from a continuous working laboratory bioreactor with almost finished cow manure. Two bioreactors were filled with inoculums only as control [7]. The others bioreactors were filled in with inoculum and biomass sample $(20.0 \mathrm{~g})$. Chopped fern $(20.0 \mathrm{~g})$ were filled in bioreactors R2-R5. Chopped thistle $20 \mathrm{~g}$ as raw material was filled in bioreactors R6 to R10. Chopped wild raspberries $20 \mathrm{~g}$ were filled in bioreactors R11 to R15. The working methods, equipment and their accuracy are the same as described in the article [7]. Total biogas and methane production values were calculated using the biogas normal volumes and quality parameters obtained from gas collected in the gas storage bag for each bioreactor as described [8]. Data of study were recorded in the experimental log and also stored in the computer.

\section{Results and discussion}

The data of raw material sample analysis and amount of biogas and methane produced were estimated for all 16 bioreactors, and average results were calculated. The results of raw material analyses before anaerobic digestion are shown in Table 1. As substrates in control bioreactors (R1, R16) the same digestates were used as were used for inoculums. Weight of total solids (TS) and dry organic matter (DOM) of raw materials samples in Table1 is provided with accuracy $\pm 0.001 \mathrm{~g}$, but for inoculum $(500 \mathrm{~g})$ with accuracy $\pm 0.02 \mathrm{~g}$. As it can be seen from Table 1 , most dry matter and dry organic matter are in wild raspberries.

Table 1

Analyses of raw material samples

\begin{tabular}{|l|l|c|c|c|c|c|c|c|}
\hline $\begin{array}{l}\text { Bio- } \\
\text { reactors }\end{array}$ & Raw material & $\mathbf{p H}$ & $\begin{array}{c}\text { TS, } \\
\mathbf{\%}\end{array}$ & $\begin{array}{c}\text { TS, } \\
\mathbf{g}\end{array}$ & $\begin{array}{c}\text { ASH, } \\
\mathbf{\%}\end{array}$ & $\begin{array}{c}\text { DOM, } \\
\mathbf{\%}\end{array}$ & $\begin{array}{c}\text { DOM, } \\
\mathbf{g}\end{array}$ & $\begin{array}{c}\text { Weight, } \\
\mathbf{g}\end{array}$ \\
\hline R1; R16 & IN & 7.80 & 1.74 & 8.700 & 29.39 & 70.61 & 6.143 & 500 \\
\hline R2-R5 & F & - & 36.76 & 7.352 & 8.26 & 91.74 & 6.745 & 20 \\
\hline R2-R5 & 20 F + 500 IN & 7.75 & 3.09 & 16.052 & 19.71 & 80.29 & 12.888 & 520 \\
\hline R6- R10 & 20 T & - & 21.45 & 4.290 & 15.76 & 84.24 & 3.614 & 20 \\
\hline R6-R10 & 20 T + 500 IN & 7.76 & 2.50 & 12.990 & 24.89 & 75.11 & 9.757 & 520 \\
\hline R11-R15 & 20 R & - & 40.57 & 8.114 & 5.55 & 94.45 & 7.664 & 20 \\
\hline R11- R15 & 20 R + 500 IN & 7.78 & 3.23 & 16.814 & 17.88 & 82.12 & 13.807 & 520 \\
\hline
\end{tabular}

Note: IN - inoculum; F - fern; T - thistle; R - wild raspberries; TS - total solids; DOM - dry organic matter (on raw substrate basis); R1-R16 - bioreactors.

Biogas and methane yield from ferns, thistles and wild raspberries are shown in Table 2. Biogas and methane values for bioreactors R2-R15 with fresh source biomass are provided with already subtracted average biogas and methane values obtained from reactors 1 and 16 . The low methane content in the produced biogas is surprising. As it is low from all biomass and all bioreactors, it is possible that there was a bad inoculum with a low methane-forming bacteria content. Methane-producing bacteria could not multiply so quickly to use all the products produced in the first stages of the process. This is 
evidenced by the relatively large amount of biogas produced, with the exception of ferns, with a very high carbon dioxide content. However, our studies before and after this study, when a similar inoculum was used, suggest that there is another explanation for the low methane production. There may be a substance in the undergrowth that inhibits the rapid growth of methane bacteria. More research is needed.

Table 2

Biogas and methane yields

\begin{tabular}{|c|c|c|c|c|c|}
\hline Bioreactor/Raw material & $\begin{array}{c}\text { Biogas, } \\
\text { L }\end{array}$ & $\begin{array}{c}\text { Biogas, } \mathrm{L}^{-\mathrm{g}^{-}} \\
1_{\text {DOM }}\end{array}$ & $\begin{array}{c}\text { Methane, } \\
\text { aver.\% }\end{array}$ & $\begin{array}{c}\text { Methane, } \\
\text { L }\end{array}$ & $\begin{array}{r}\text { Methane, } \\
\mathbf{L} \cdot \mathrm{g}^{-1} \text { DOM }\end{array}$ \\
\hline R1 500 IN & 0.2 & 0.033 & 1.10 & 0.002 & 0.0003 \\
\hline R16 500 IN & 0.3 & 0.049 & 5.33 & 0.016 & 0.0030 \\
\hline Average R1, R16 & 0.25 & 0.041 & 3.22 & 0.009 & 0.0017 \\
\hline R2 500 g IN + 20 g F & 1.4 & 0.208 & 24.71 & 0.346 & 0.0510 \\
\hline R3 500 g IN + 20 g F & 2.1 & 0.311 & 28.14 & 0.591 & 0.0880 \\
\hline R4 500 g IN + 20 g F & 1.8 & 0.267 & 13.22 & 0.238 & 0.0350 \\
\hline R5 500 g IN + 20 g F & 2.1 & 0.311 & 21.10 & 0.443 & 0.0660 \\
\hline $\begin{array}{l}\text { Average R2- R5 } \\
\pm \text { st.dev. }\end{array}$ & $\begin{array}{l}1.850 \\
0.332 \\
\end{array}$ & $\begin{array}{l}0.274 \\
0.049 \\
\end{array}$ & $\begin{array}{c}21.890 \\
6.397 \\
\end{array}$ & $\begin{array}{c}0.405 \\
0.15\end{array}$ & $\begin{array}{l}0.0600 \\
0.0230\end{array}$ \\
\hline R6 500 g IN + 20 g T & 2.5 & 0.692 & 32.52 & 0.813 & 0.2250 \\
\hline R7 $500 \mathrm{~g} \mathrm{IN}+20 \mathrm{~g} \mathrm{~T}$ & 2.5 & 0.692 & 39.84 & 0.996 & 0.2760 \\
\hline R8 500 g IN + 20 g T & 2.5 & 0.692 & 32.12 & 0.803 & 0.2220 \\
\hline R9 $500 \mathrm{~g} \mathrm{IN}+20 \mathrm{~g} \mathrm{~T}$ & 2.4 & 0.664 & 39.42 & 0.946 & 0.2620 \\
\hline $\mathrm{R} 10500 \mathrm{~g} \mathrm{IN}+20 \mathrm{~g} \mathrm{~T}$ & 2.8 & 0.774 & 38.14 & 1.068 & 0.2960 \\
\hline $\begin{array}{l}\text { Average R6-R10 } \\
\pm \text { st.dev. }\end{array}$ & $\begin{array}{l}2.540 \\
0.152\end{array}$ & $\begin{array}{l}0.703 \\
0.042\end{array}$ & $\begin{array}{l}36,42 \\
3,787\end{array}$ & $\begin{array}{l}0.925 \\
0.115\end{array}$ & $\begin{array}{l}0.2560 \\
0.0320\end{array}$ \\
\hline R11 $500 \mathrm{~g} \mathrm{IN}+20 \mathrm{~g} \mathrm{R}$ & 4.0 & 0.522 & 36.55 & 1.462 & 0.1910 \\
\hline $\mathrm{R} 12500 \mathrm{~g}$ IN $+20 \mathrm{~g} \mathrm{R}$ & 4.4 & 0.574 & 39.89 & 1.755 & 0.2290 \\
\hline $\mathrm{R} 13500 \mathrm{~g} \mathrm{IN}+20 \mathrm{~g} \mathrm{R}$ & 3.8 & 0.496 & 35.79 & 1.360 & 0.1770 \\
\hline R14 500 g IN + 20 g R & 4.0 & 0.522 & 40.68 & 1.627 & 0.2120 \\
\hline R15 $500 \mathrm{~g}$ IN + $20 \mathrm{~g} \mathrm{R}$ & 3.4 & 0.444 & 32.91 & 1.119 & 0.1460 \\
\hline $\begin{array}{l}\text { Average R11- R15 } \\
\pm \text { st.dev. }\end{array}$ & $\begin{array}{l}3.920 \\
0.363 \\
\end{array}$ & $\begin{array}{l}0.511 \\
0.047 \\
\end{array}$ & $\begin{array}{c}37.370 \\
3.168\end{array}$ & 1.4650 .246 & $\begin{array}{l}0.1910 \\
0.0320\end{array}$ \\
\hline
\end{tabular}

Note: $\mathrm{L} \cdot \mathrm{g}^{-1}$ DOM - litres per $1 \mathrm{~g}$ dry organic matter added (added fresh biomass into inoculums).

The specific biogas and methane yields from ferns, thistles and wild raspberries from every bioreactor are shown in Figure 1.

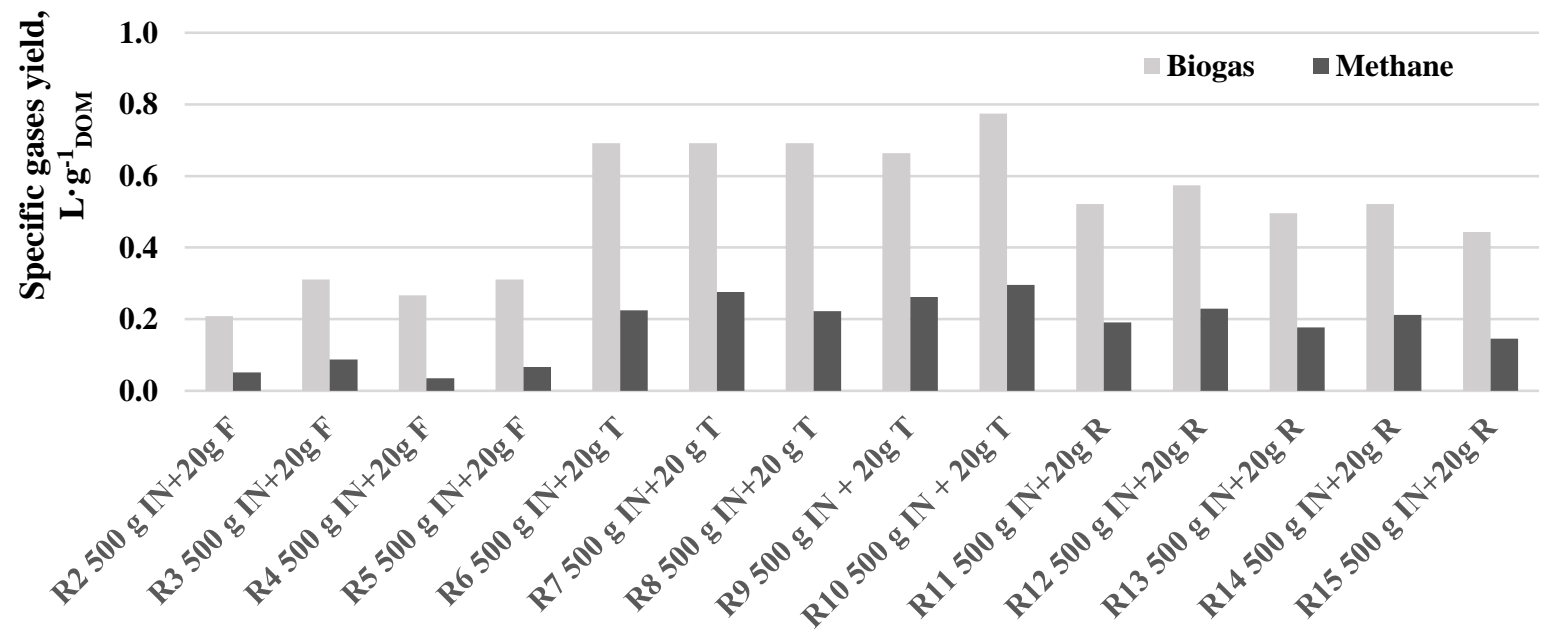

Fig. 1. Specific biogas and methane yield from ferns, thistles and wild raspberries from every bioreactor 
The best methane potential was from thistle, then from wild raspberries and small from ferns. This could be partly explained by the fact that this difference between thistles and ferns is due to the large number of stalks in the chopped ferns. The ferns were also drier.

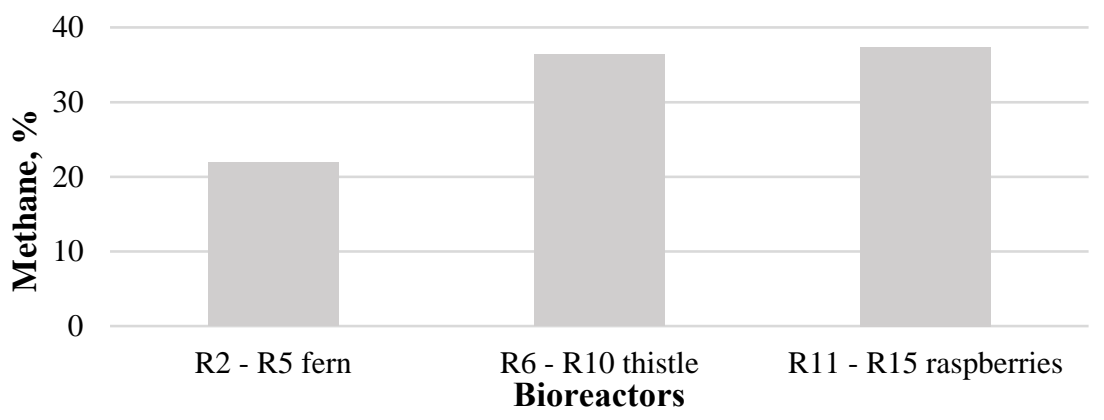

Fig. 2. Average methane content from ferns, thistles and wild raspberries

We could not compare with the results of other researchers, because they could not be found in the literature. Comparing the methane extraction potential with the methane extraction potential of other raw materials, it can be seen that for thistle it is somewhat similar to pig manure $\left(0.250 \mathrm{~L} \cdot \mathrm{g}^{-1} \mathrm{DoM}\right)$, but for wild raspberries it is somewhat similar to that of cow manure $\left(0.185 \mathrm{~L} \cdot \mathrm{g}^{-1}\right.$ DOM $)$ [8].

\section{Conclusions}

1. The average yield of biogas (methane) from the bioreactors with fern was $0.274 \pm 0.049 \mathrm{~L} \cdot \mathrm{g}^{-1} \mathrm{DOM}$ $\left(0.06 \pm 0.023 \mathrm{~L} \cdot \mathrm{g}^{-1}\right.$ DOM $)$.

2. The average yield of biogas (methane) from the bioreactors with added thistle was $0.703 \pm 0.042$ $\mathrm{L} \cdot \mathrm{g}^{-1}$ DOM $\left(0.256 \pm 0.032 \mathrm{~L} \cdot \mathrm{g}^{-1}\right.$ DOM $)$.

3. The average yield of biogas from the bioreactors with added raspberry was $0.511 \pm 0.047 \mathrm{~L} \cdot \mathrm{g}^{-1} \mathrm{DOM}$ $\left(0.191 \pm 0.032 \mathrm{~L} \cdot \mathrm{g}^{-1}\right.$ DOM $)$.

4. The average yields of biogas and methane from the bioreactors with added fern were low.

5. Using fern as raw material alone for methane production is not acceptable.

6. Thistle and wild raspberries can be usable raw materials for biogas production, but better together with other raw materials.

\section{Acknowledgements}

This work has been supported by the project G4 "Feasibility Study of Biomass Anaerobic Fermentation Process Efficiency".

\section{References}

[1] EBA Statistical report 2020 abridged publication $14 \mathrm{p}$.

[2] Dubrovskis V., Adamovics A., Bioenergeêtikas horizonti (Horizons of bioenergetics) (In Latvian), 2012, $352 \mathrm{p}$.

[3] Mehrdadfar A., Amidpour M., Bashiri N., Akhavan A. Compare the ability to generate electricity by Azolla fern s biogas in different systems of small scale CHP. Journal of Fundamentals of Renewable Energy and Applications 2016, 6:3 pp. 40. DOI: 10.4172/2090-4541.C1.008

[4] VDI 4630. Vergärung organischer Stoffe Substrat charakterisierung, Probenahme, Stoffdatenerhebung, Gärversuche. Vereindeutscher Ingenieure (Fermentation of organic substances Substrate characterization, sampling, substance data collection, fermentation tests. German engineers), Düsseldorf, 2006, 48 p. (In German).

[5] Angelidaki I., Alves M., Bolzonella D., Borzacconi L., Campos J., Guwy A., Kalyuzhnyi S., Jenicek P., Van Lier J. Defining the biomethane potential (BMP) of solid organic wastes and energy crops: a proposed protocol for batch assays. Water Sci Technol. 2009, 59(5): pp. 927-934.

[6] Thran D. Methodenhandbuch Energetische Biomassenutzung, (Methods Manual Energetic use of biomass), 2010, Leipzig, 161 p. (In German).

[7] Dubrovskis V., Plume I. and Straume I. The production of methane from the straw pellets with addition of enzymes Agronomy Research 2019, 17(4), pp. 1591-1598. DOI: 10.15159/AR.19.180

[8] Becker C., Dohler H., H. Eckel, et al. Faustzahlen biogas KTBL, FNR 2007181 p. 